\title{
1 Whole-genome analysis of Malawian Plasmodium falciparum isolates identifies potential 2 targets of allele-specific immunity to clinical malaria
}

3
Zalak Shah ${ }^{1}$, Myo T. Naung ${ }^{2,3,4}$, Kara A. Moser ${ }^{5}$, Matthew Adams ${ }^{1}$, Andrea G. Buchwald ${ }^{1}$, Ankit Dwivedi $^{5}$, Amed Ouattara ${ }^{1}$, Karl B Seyde ${ }^{6,7}$, Don P. Mathanga ${ }^{8}$, Alyssa E. Barry ${ }^{2,3,4,9}$, David Serre $^{5}$, Miriam K. Laufer ${ }^{1}$, Joana C. Silva ${ }^{5}$, and Shannon Takala-Harrison ${ }^{1}$

${ }^{1}$ Center for Vaccine Development and Global Health, University of Maryland School of Medicine, Baltimore, MD, 21201, USA.

2Population Health and Immunity Division, Walter Eliza Hall of Medical Institute for Medical Research, Parkville, Victoria, Australia

${ }^{3}$ Department of Medical Biology, University of Melbourne, Carlton, Victoria, Australia ${ }^{4}$ School of Medicine, Deakin University, Geelong, Victoria, Australia

${ }^{5}$ Institute for Genome Sciences, University of Maryland School of Medicine, Baltimore, MD, 21201, USA.

${ }^{6}$ Department of Osteopathic Medical Specialties, College of Osteopathic Medicine, Michigan State University, East Lansing, Michigan, 48824, USA.

${ }^{7}$ Blantyre Malaria Project, University of Malawi College of Medicine, Blantyre, Malawi, Africa. ${ }^{8}$ University of Malawi College of Medicine, Malaria Alert Centre, Blantyre, Malawi.

${ }^{9}$ Disease Elimination and Maternal and Child Health, Burnet Institute, Melbourne, Victoria, Australia

Corresponding author: Shannon Takala-Harrison stakala@som.umaryland.edu 
medRxiv preprint doi: https://doi.org/10.1101/2020.09.16.20196253; this version posted September 18, 2020. The copyright holder for this preprint (which was not certified by peer review) is the author/funder, who has granted medRxiv a license to display the preprint in perpetuity.

It is made available under a CC-BY-NC-ND 4.0 International license .

\section{Abstract}

26

27 Individuals acquire immunity to clinical malaria after repeated Plasmodium falciparum infections.

28 This immunity to disease is thought to reflect the acquisition of a repertoire of responses to

29 multiple alleles in diverse parasite antigens. In previous studies, we identified polymorphic sites

30 within individual antigens that are associated with parasite immune evasion by examining antigen

31 allele dynamics in individuals followed longitudinally. Here we expand this approach by analyzing

32 genome-wide polymorphisms using whole genome sequence data from 140 parasite isolates

33 representing malaria cases from a longitudinal study in Malawi and identify 25 genes that encode

34 likely targets of naturally acquired immunity and that should be further characterized for their

35 potential as vaccine candidates. 
medRxiv preprint doi: https://doi.org/10.1101/2020.09.16.20196253; this version posted September 18, 2020. The copyright holder for this

preprint (which was not certified by peer review) is the author/funder, who has granted medRxiv a license to display the preprint in perpetuity.

It is made available under a CC-BY-NC-ND 4.0 International license .

\section{INTRODUCTION}

38 Despite recent progress in reducing the burden of malaria, this disease remains a leading cause

39 of mortality worldwide, resulting in an estimated 405,000 deaths in 2018 (WHO / World Malaria

40 Report 2018, n.d.). In areas with high transmission of Plasmodium falciparum, individuals develop

41 immunity to malaria (Marsh \& Kinyanjui, 2006). This immunity does not provide sterile protection

42 against all infections, but decreases the risk of clinical disease, and increases with age as

43 individuals are repeatedly exposed to the parasite (Cowman et al., 2016; Ryg-Cornejo et al.,

44 2016). This age-related pattern of immunity to disease is thought to reflect the need for a

45 repertoire of immune responses to multiple alleles in diverse parasite antigens (Buchwald, Sorkin,

46 et al., 2019; Cowman et al., 2016; Marsh \& Kinyanjui, 2006; Portugal et al., 2013). The extensive

47 genetic diversity in $P$. falciparum surface antigens is thought to have evolved over millennia as a

48 means of parasite immune evasion (Weedall \& Conway, 2010). Allele-specific immune responses

49 have been demonstrated for several parasite antigens (Barry et al., 2011; Cortés et al., 2005;

50 Crompton et al., 2010; Dutta et al., 2007; Early et al., 2018; Osier et al., 2008; Polley et al., 2007;

51 Tran et al., 2014). In previous work, we examined parasite alleles in repeated infections occurring

52 in individuals followed longitudinally and identified specific polymorphic sites within parasite

53 surface antigens (i.e. AMA1 and MSP1) where amino acid changes were associated with immune

54 escape and increased risk of disease, consistent with allele-specific acquisition of immunity to

55 these antigens (Takala et al., 2007, 2009). Furthermore, malaria subunit vaccines based on a

56 single antigen allele have displayed greater efficacy against parasites with alleles matching the

57 vaccine strain compared to the diverse alleles observed in natural parasite populations (Ouattara

58 et al., 2013, 2015; Takala et al., 2009; Thera et al., 2011). Such allele-specific vaccine efficacy

59 could lead to poor overall vaccine efficacy when the vaccine target allele is at low frequency in

60 the parasite population and could result in selection of non-vaccine alleles capable of vaccine

61 escape (Ouattara et al., 2015). Overcoming this scenario may require the design of a multivalent 
medRxiv preprint doi: https://doi.org/10.1101/2020.09.16.20196253; this version posted September 18, 2020. The copyright holder for this preprint (which was not certified by peer review) is the author/funder, who has granted medRxiv a license to display the preprint in perpetuity.

It is made available under a CC-BY-NC-ND 4.0 International license .

62 malaria vaccine (Ouattara et al., 2015). However, the design of such a vaccine is hampered by

63 an incomplete knowledge of which parasite proteins are targets of acquired natural immunity.

64 The advent of technologies allowing whole genome sequencing at epidemiological scales

65 has allowed investigators to transition from investigation of single antigens to performing genome-

66 wide screens to identify loci likely to be involved in the acquisition of protective immunity to

67 malaria, including uncharacterized genes encoding products of unknown function (Gardner et al.,

68 2002; PlasmoDB: The Plasmodium Genomics Resource, n.d.). Although there have been

69 previous genome-wide studies in $P$. falciparum to identify genomic signatures of balancing or

70 diversifying selection at a population level (Amambua-Ngwa et al., 2012; Mobegi et al., 2014; Mu

71 et al., 2007), these studies do not associate identified signatures with clinical outcomes at an

72 individual level, making it difficult to directly link such signatures to immune selection. Expanding

73 on our previous approach where we examined the dynamics of vaccine antigen alleles in

74 individuals' repeated infections over time in relation to the development of symptoms (Takala et

75 al., 2007, 2009), we compared whole genome sequence data generated from $P$. falciparum

76 infections collected from participants in a longitudinal cohort study conducted in Malawi to identify

77 targets of allele-specific immunity to malaria. Specifically, we compared the frequency of parasite

78 alleles in symptomatic infections occurring in individuals with different levels of malaria immunity

79 to identify significantly differentiated sites, and also compared alleles in repeated infections within

80 an individual versus between individuals to identify polymorphic sites that vary most within

81 individuals. Genes identified using both approaches were considered likely immune targets and

82 were further examined for their potential as vaccine candidates. As a proof of concept of the utility

83 of our approach in identifying targets of allele-specific immune responses, we compared the

84 frequency of alleles in one of the identified antigens (previously considered as a potential vaccine

85 candidate) in individuals with different levels of malaria immunity to test the hypothesis that

86 individuals who are more immune become ill when infected with a parasite having rarer alleles to

87 which they have not yet developed immunity. 
medRxiv preprint doi: https://doi.org/10.1101/2020.09.16.20196253; this version posted September 18, 2020. The copyright holder for this preprint (which was not certified by peer review) is the author/funder, who has granted medRxiv a license to display the preprint in perpetuity.

It is made available under a CC-BY-NC-ND 4.0 International license.

\section{RESULTS}

\section{Participant/infection characteristics and definition of immune status}

90 To identify targets of allele-specific immunity to malaria, we generated whole-genome sequence

91 data from 140 parasite isolates collected from symptomatic infections occurring in participants in

92 a longitudinal cohort study in Malawi (Buchwald, Sixpence, et al., 2019).

Although age is often used as a proxy for immune status in high transmission areas (Egan et al., 1996; Metzger et al., 2003; Perraut et al., 2017; Tran et al., 2014), this metric does not

95 account for heterogeneous exposure to infectious mosquito bites, which has been observed in

96 endemic areas (Bejon et al., 2010; Bousema et al., 2010; Clark et al., 2008; Elissa et al., 2003;

97 Gaudart et al., 2006; Kang et al., 2018). To better account for heterogeneous exposure at an

98 individual level, we used the proportion of total infections that were symptomatic over the two-

99 year study period to categorize immune status, using the median as a cutoff to define high and

100 low immunity groups. Although these groups consisted of individuals with a range of ages, the 101 median age (13.18 years) of individuals in the group with high immunity was significantly greater

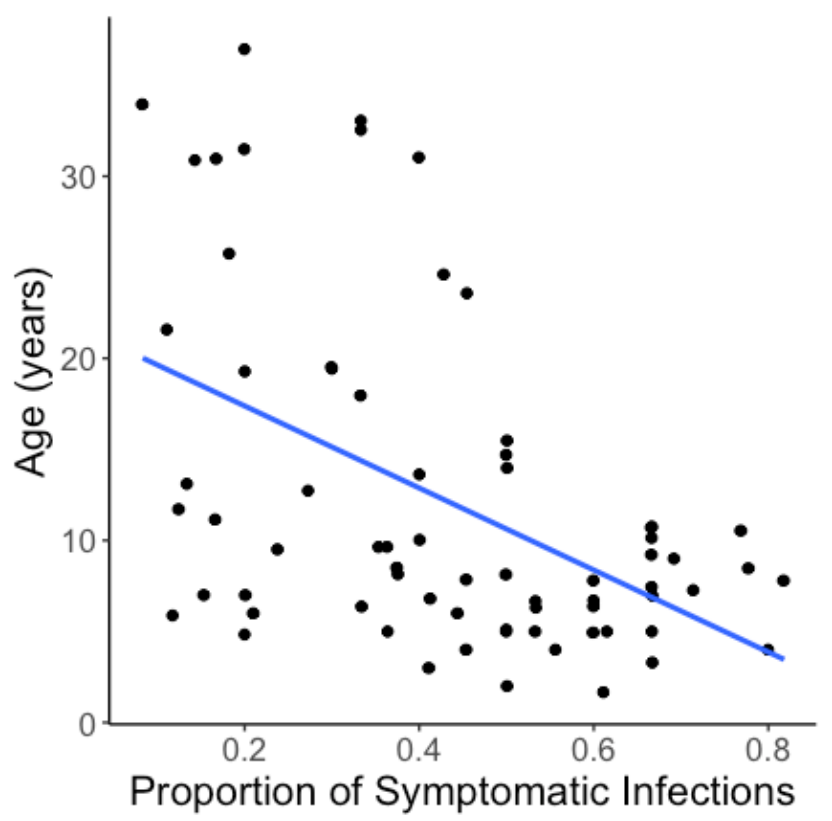

Figure 1. Relationship between proportion of symptomatic infections and age. Scatterplot, including linear regression line (blue), shows the relationship between the proportion of symptomatic infections per individual over the course of the study and age of the individual at enrollment. 
medRxiv preprint doi: https://doi.org/10.1101/2020.09.16.20196253; this version posted September 18, 2020. The copyright holder for this preprint (which was not certified by peer review) is the author/funder, who has granted medRxiv a license to display the preprint in perpetuity.

It is made available under a CC-BY-NC-ND 4.0 International license .

102 than the median age (7.27 years) of individuals in the low immunity group ( $p$-value $=0.0001$,

103 Wilcoxon rank sum test) (Figure 1, Table 1), as would be expected in a high malaria transmission

104 setting such as Malawi.

105 Only one infection from each individual was included in comparisons between the high

106 and low immunity groups, with samples selected in a manner to reduce temporal variability

107 between infections (see Methods). DEploid-IBD (Zhu et al., 2017) was used to estimate the

108 proportion of each clone within an infection. Infections without a predominant clone (i.e., where

109 the majority clone had a frequency $<60 \%$ within the infection) were defined as complex infections.

110 Although the median frequency of the majority clone was not significantly different between

111 infections in the two immunity groups (Supplementary Fig $1, p$-value $=0.3372$, Wilcoxon rank sum

112 test), the high immunity group had a greater number of complex infections $(n=7)$ than the low

113 immunity group $(n=2)$. These nine complex infections were excluded from further analysis to avoid

114 confounding by infection complexity and misclassification of alleles likely contributing to clinical

115 illness.

Table 1. Participant/infection characteristics in high and low immunity groups ${ }^{\#}$

\begin{tabular}{lccc}
\hline Characteristics & $\begin{array}{c}\text { High Immunity } \\
(\mathbf{n}=\mathbf{2 8})\end{array}$ & $\begin{array}{c}\text { Low Immunity } \\
(\mathbf{n}=\mathbf{3 3})\end{array}$ & $\boldsymbol{P}$-value \\
\hline Median age (years) & 13.18 & 7.27 & $0.0002^{+}$ \\
Male (\%) & 36 & 52 & $0.33^{*}$ \\
Median parasitemia (parasites/uL) & 4710 & 48200 & $7.74 \mathrm{e}-06^{+}$ \\
Median genome coverage 20x (\%) & 88.73 & 90.14 & $0.2673^{+}$ \\
Median depth of coverage & $130 \mathrm{x}$ & $156 \mathrm{x}$ & $0.2485^{+}$ \\
\hline
\end{tabular}

\#High complexity infections lacking a predominant parasite clone were excluded

${ }^{*} P$-value determined using z-score test for difference in proportions

$+P$-value determined using Wilcoxon rank sum test 
medRxiv preprint doi: https://doi.org/10.1101/2020.09.16.20196253; this version posted September 18, 2020. The copyright holder for this preprint (which was not certified by peer review) is the author/funder, who has granted medRxiv a license to display the preprint in perpetuity.

It is made available under a CC-BY-NC-ND 4.0 International license .

The median parasite density of infections in the high immunity group was significantly

lower than in the low immunity group (Table $1, p$-value $=7.737 \times 10^{-06}$, Wilcoxon rank sum test).

119 However, there was no significant difference in the percentage of the parasite genome with at

120 least 20-fold coverage (Table $1, p$-value $=0.2673$, Wilcoxon rank sum test), or in the median

121 average depth of coverage (Table $1, p$-value $=0.2485$, Wilcoxon rank sum test) between whole

122 genome sequence data generated from infections in the two groups.

124 Differentiated loci between groups with different levels of immunity to clinical malaria

125 We hypothesized that, because of allele-specific immune responses, individuals with greater

126 protective immunity to malaria would experience disease when infected with parasite antigen

127 alleles that are rarer in the parasite population, having already developed immunity to more

128 common alleles circulating in the population. Thus, we would expect significant genetic

129 differentiation between antigen alleles in individuals with high versus low immunity at loci that are

130 targets of allele-specific immunity.

131 To test this hypothesis, Wright's fixation index $\left(F_{\mathrm{ST}}\right)$, a measure of genetic differentiation

132 between two populations (Bhatia et al., 2013), was estimated per non-synonymous single

133 nucleotide polymorphism (SNP) to identify genetically differentiated sites between parasites from

134 the high and low immunity groups with the significance threshold based on 10,000 permutations.

135 We identified 160 sites (in 145 genes) in the parasite genome that were significantly differentiated

136 between the two immunity groups ( $p$-value $\leq 0.0095$, Figure $2 a$, Supplementary Table 1$)$. Fifty-

137 five of the genes containing significantly differentiated sites (38\%) encode proteins of unknown

138 function that are not associated with any computed or curated molecular function or biological

139 process based on Gene Ontology (Supplementary Table 1). These 145 gene products included

140 some proteins previously identified as potential vaccine candidates, including AMA1 (apical

141 membrane antigen 1) (Takala et al., 2009; Thera et al., 2011, p. 20), ASP (apical sushi protein, 
medRxiv preprint doi: https://doi.org/10.1101/2020.09.16.20196253; this version posted September 18, 2020. The copyright holder for this preprint (which was not certified by peer review) is the author/funder, who has granted medRxiv a license to display the preprint in perpetuity.

It is made available under a CC-BY-NC-ND 4.0 International license .

PF3D7_0405900) (Vanegas et al., 2014), CLAG8 (cytoadherence linked asexual protein 8,

143 PF3D7_0831600) (Gupta et al., 2015; Iriko et al., 2008), SLARP (sporozoite and liver asparagine-

144 rich protein, PF3D7_1147000) (van Schaijk et al., 2014) and a conserved protein of unknown

145 function (PF3D7_1359000) (Krzyczmonik et al., 2012).
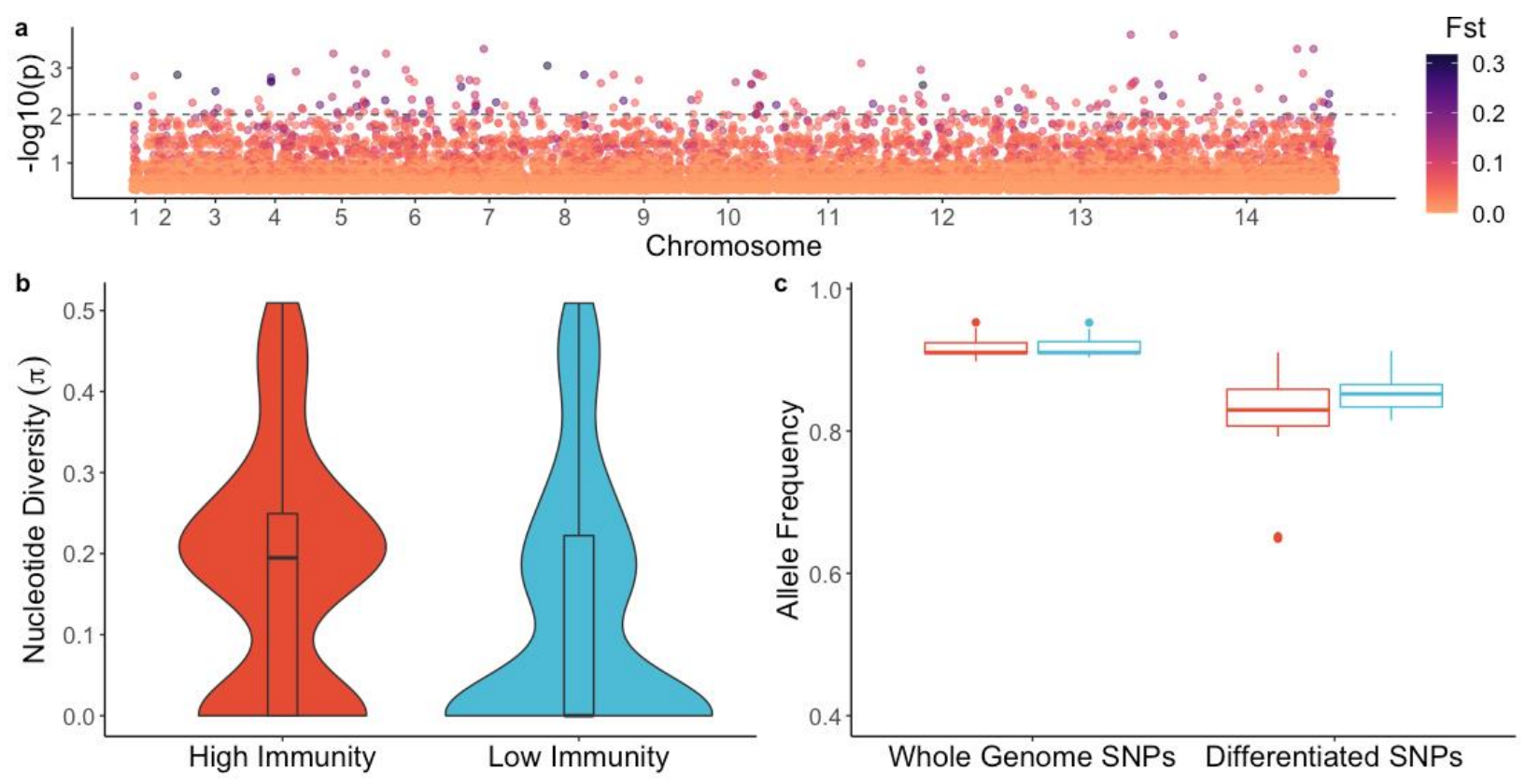

Figure 2. Genetic differentiation between parasites from high immunity vs. low immunity groups. a) Genome-wide genetic differentiation $\left(F_{\mathrm{ST}}\right)$ between parasites from individuals with higher immunity vs. lower immunity. Each point represents a variable, non-synonymous site. Results are plotted as $-\log _{10} p$-values on the y-axis. The color of each point represents the $F_{\text {ST }}$ value, with darker points indicating higher $F_{\mathrm{ST}}$ values. The dashed line denotes statistical significance ( $p$-value $=0.0095$ ), with $p$-value determined by permutation. b) Nucleotide diversity for significantly differentiated SNPs in parasites from individuals with higher immunity and lower immunity. c) Box-plot of mean allele frequency per individual based on SNPs in the whole genome sequences, and which are significantly differentiated SNPs from (a). Red indicates the high immunity group and blue color indicates the low immunity group.

147 To further test the hypothesis that individuals who are more immune become symptomatic when

148 infected with parasites having antigen alleles that are rarer in the parasite population, we 149 estimated nucleotide diversity at significantly differentiated non-synonymous sites in parasites 150 from the two immunity groups and observed a significantly greater median nucleotide diversity in 
medRxiv preprint doi: https://doi.org/10.1101/2020.09.16.20196253; this version posted September 18, 2020. The copyright holder for this preprint (which was not certified by peer review) is the author/funder, who has granted medRxiv a license to display the preprint in perpetuity.

It is made available under a CC-BY-NC-ND 4.0 International license .

151 parasites from the high immunity group compared to parasites from the low immunity group

152 (Figure $2 \mathrm{~b}, p$-value $=4.74 \times 10^{-05}$, Wilcoxon rank sum test). In addition, we estimated the average

153 frequency of alleles in each infection at both significantly differentiated sites and genome-wide

154 variable sites. The median frequency of alleles at genome-wide variable sites was not significantly

155 different between immunity groups (Figure 2c, $p$-value $=0.8801$, Wilcoxon rank sum test); in

156 contrast, at the differentiated sites, the median frequency of alleles was significantly lower in the

157 high immunity group compared to the low immunity group (Figure $2 \mathrm{c}, p$-value $=0.0072$, Wilcoxon

158 rank sum test). These results are consistent with the scenario that individuals in the high immunity

159 group are infected with parasites having different lower-frequency alleles compared to individuals

160 in the low immunity group who are infected with parasites sharing more common alleles.

Within 23 polyclonal infections, we also compared the proportion of mismatched alleles

162 between the predominant and minor clones at both significantly differentiated sites and genome-

163 wide variable sites in order to assess whether these clones differ at sites thought to be relevant

164 for immunity. We observed a significantly greater median proportion of mismatches between the

165 major and minor clones within an infection at the differentiated sites compared to genome-wide

166 variable sites (Supplementary Figure 2, $p$-value $=8 \times 10^{-05}$, Wilcoxon rank sum test), consistent

167 with the hypothesis that the predominant clone represents a breakthrough infection that has

168 escaped allele-specific immune responses that maintain minor clones at a subclinical level.

\section{Loci that differ more within individuals than between individuals}

171 We expected that allele-specific immune responses would result in a greater proportion of

172 genetic differences in parasites causing multiple symptomatic infections within an individual

173 compared to parasites causing infection in different individuals, at antigenic loci that are targets

174 of immunity. To identify regions of the parasite genome that are most different in infections

175 occurring within an individual versus between individuals, we compared the allelic states at each 
medRxiv preprint doi: https://doi.org/10.1101/2020.09.16.20196253; this version posted September 18, 2020. The copyright holder for this preprint (which was not certified by peer review) is the author/funder, who has granted medRxiv a license to display the preprint in perpetuity.

It is made available under a CC-BY-NC-ND 4.0 International license .

176 variable non-synonymous site across the genome between pairs of isolates sampled within an

177 individual and between individuals and estimated the proportion of mismatches per site in each

178 group (Figure 3a). The distribution of the difference in the proportion of mismatches across all

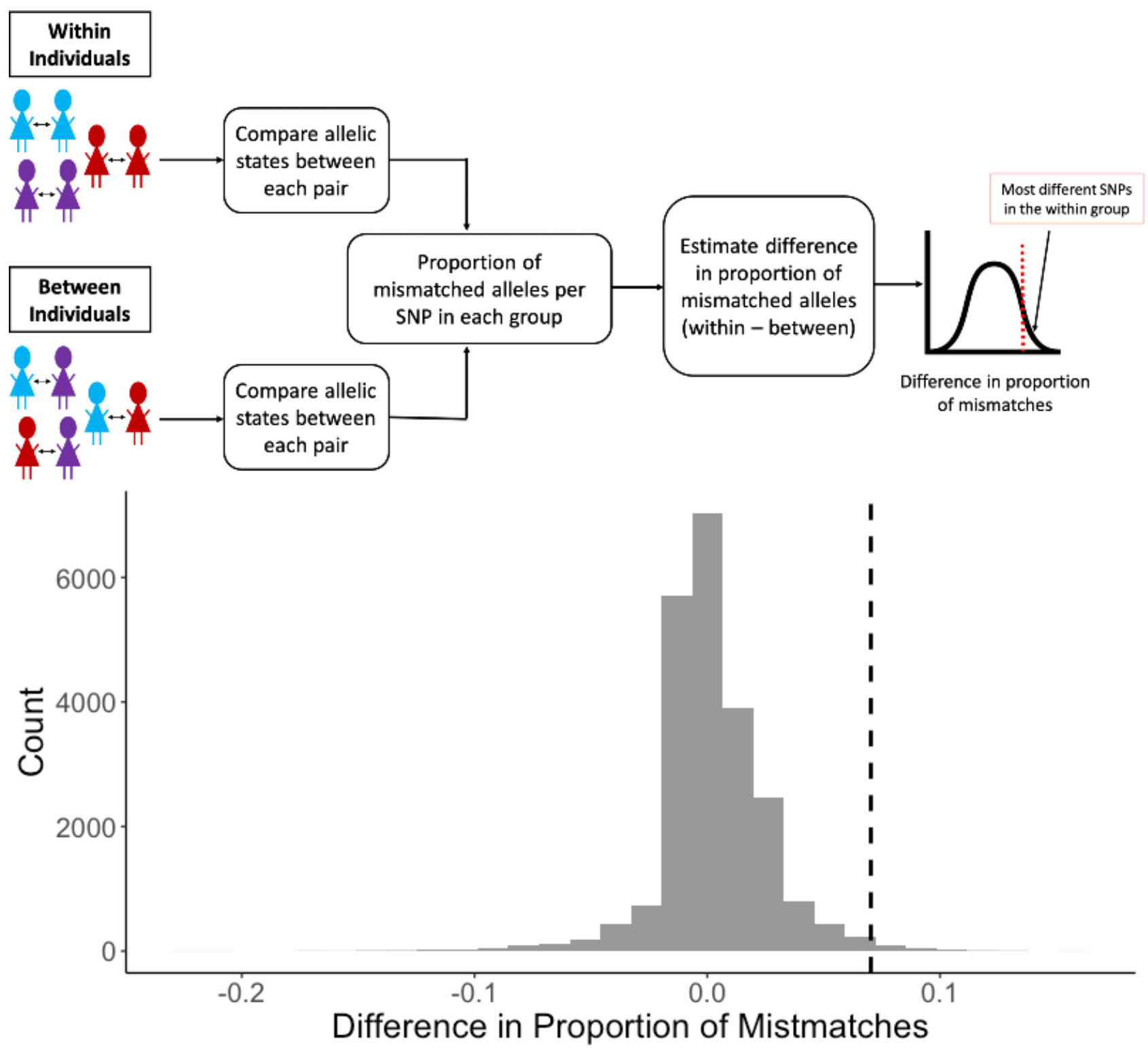

Figure 3. Analysis of mismatches in paired samples within and between individuals. a) Illustration of analysis to identify regions of the genome that vary more in parasites causing illness within the same individual over time (within individuals) compared to random pairs of parasites in the population (between individuals). b) Distribution of differences in the proportion of mismatched alleles in the within group and the between group. The difference was calculated as the proportion of mismatches at each non-synonymous SNP in the within group minus the proportion of mismatches at each non-synonymous SNP in the between group. The dashed black line indicates the threshold for the top $1 \%$ most different SNPs in the within group compared to the between group. 
medRxiv preprint doi: https://doi.org/10.1101/2020.09.16.20196253; this version posted September 18, 2020. The copyright holder for this preprint (which was not certified by peer review) is the author/funder, who has granted medRxiv a license to display the preprint in perpetuity.

It is made available under a CC-BY-NC-ND 4.0 International license .

179 non-synonymous variable sites between the two groups (within minus between) is shown in

180 Figure 3b (see also Supplementary Fig 3a). The difference in the proportion of mismatches at

181 each site had a median and mode equal to zero, indicating that the proportion of mismatches was

182 not different within and between individuals at most sites. There was no significant correlation

183 between the number of days between infections in a pair and the proportion of mismatches

184 (Supplementary Fig 2b, Pearson's correlation $r=0.065, p$-value $=0.3043$ ), suggesting that time

185 was not a significant confounding factor in the analysis. We further examined the top $1 \%$ of sites

186 that differed most within individuals compared to between individuals, which included 223 SNPs,

187 located in 173 genes (Supplementary Table 2). Sixty-eight (39\%) of these 173 genes encode

188 proteins of unknown function that are not associated with any computed or curated molecular

189 function or biological process based on Gene Ontology, and at least $15(8.7 \%)$ encode for proteins

190 that have been previously identified as potential vaccine candidates.

Loci identified as likely targets of immunity by both analytical approaches

193 Twenty-five genes were identified by both analytical approaches, of which 11 (44\%) encode

194 proteins of unknown function (Table 2). Based on publicly available data, 20 of the 25 genes have

195 a moderate to high level of expression in the erythrocytic stage of the parasite life cycle (Toenhake

196 et al., 2018) (Supplementary Table 3). Eight genes have a mutagenesis index score near zero,

197 suggesting that they are likely essential (Zhang et al., 2018), and at least 12 genes have either a

198 known or a predicted transmembrane domain or a signal peptide (PlasmoDB: A Functional

199 Genomic Database for Malaria Parasites. - PubMed - NCBI, n.d.). Among these 25 gene products

200 are proteins whose putative function make them biologically plausible vaccine candidates,

201 including SURFIN4.2 (thought to be involved in formation of the moving junction during

202 erythrocyte invasion) (Quintana et al., 2018), as well as members of the CLAG and PHIST

203 multigene families (both thought to have a role in parasite cytoadherence) (Holt et al., 1999;

204 Proellocks et al., 2014). 
Table 2. Gene products identified as likely targets of allele-specific immunity to malaria based on two analytical approaches.

\begin{tabular}{|c|c|c|c|}
\hline Gene ID & Annotation & GO Function & GO Process \\
\hline PF3D7_0311900 & heptatricopeptide repeat-containing protein, putative & null & null \\
\hline PF3D7_0312500 & major facilitator superfamily-related transporter, putative & null & transmembrane transport \\
\hline PF3D7_0318200 & DNA-directed RNA polymerase II subunit RPB1 & $\begin{array}{c}\text { DNA-directed 5'-3' RNA polymerase } \\
\text { activity } \\
\end{array}$ & transcription \\
\hline PF3D7_0412300 & phosphopantothenoylcysteine synthetase, putative & null & null \\
\hline PF3D7_0421700 & conserved Plasmodium protein, unknown function & null & null \\
\hline PF3D7_0424400 & surface-associated interspersed protein 4.2 (SURFIN 4.2) & host cell surface binding & entry into host cell \\
\hline PF3D7_0511500 & RNA pseudouridylate synthase, putative & $\begin{array}{l}\text { RNA binding, pseudouridine synthase } \\
\text { activity }\end{array}$ & RNA modification, pseudouridine synthesis \\
\hline PF3D7_0522400 & conserved Plasmodium protein, unknown function & null & protein localization/transport \\
\hline PF3D7_0526600 & conserved Plasmodium protein, unknown function & null & lipid biosynthetic process \\
\hline PF3D7_0605600 & nucleoside diphosphate kinase, putative & nucleoside diphosphate kinase activity & nucleoside diphosphate phosphorylation \\
\hline PF3D7_0619600 & conserved Plasmodium protein, unknown function & null & null \\
\hline PF3D7_0704600 & E3 ubiquitin-protein ligase & ubiquitin-protein transferase activity & response to drug \\
\hline PF3D7_0710200 & conserved Plasmodium protein, unknown function & null & null \\
\hline PF3D7_0807700 & serine protease DegP & serine-type endopeptidase activity & $\begin{array}{l}\text { response to oxidative stress and } \\
\text { temperature stimulus }\end{array}$ \\
\hline PF3D7_0831600 & cytoadherence linked asexual protein 8 & null & null \\
\hline PF3D7_0914300 & met- $10+$ like protein, putative & null & null \\
\hline PF3D7_1004200 & WD repeat-containing protein, putative & protein binding & transport \\
\hline PF3D7_1030400 & conserved protein, unknown function & null & null \\
\hline PF3D7_1033100 & S-adenosylmethionine/Ornithine decarboxylase & $\begin{array}{l}\text { adenosylmethionine decarboxylase } \\
\text { activity }\end{array}$ & $\begin{array}{l}\text { spermidine/spermine biosynthetic } \\
\text { processes }\end{array}$ \\
\hline PF3D7_1035100 & probable protein, unknown function & ATP binding & null \\
\hline PF3D7_1102500 & Plasmodium exported protein (PHISTb), unknown function & null & null \\
\hline PF3D7_1149600 & DnaJ protein, putative & null & null \\
\hline PF3D7_1219100 & clathrin heavy chain, putative & $\begin{array}{l}\text { clathrin light chain binding, structural } \\
\text { molecule activity }\end{array}$ & $\begin{array}{c}\text { clathrin coat assembly, intracellular protein } \\
\text { transport, vesicle-mediated transport }\end{array}$ \\
\hline PF3D7_1465800 & dynein beta chain, putative & ATP binding, microtubule motor activity & microtubule-based movement \\
\hline PF3D7_1475900 & KELT protein & null & null \\
\hline
\end{tabular}


medRxiv preprint doi: https://doi.org/10.1101/2020.09.16.20196253; this version posted September 18, 2020. The copyright holder for this preprint (which was not certified by peer review) is the author/funder, who has granted medRxiv a license to display the preprint in perpetuity.

It is made available under a CC-BY-NC-ND 4.0 International license .

As a proof of concept of the utility of our approach for identifying targets of allele-specific

208 immunity, we used publicly available sequence data from Pf3K (Pf3k Pilot Data Release 5 /

209 MalariaGEN, n.d.) combined with 156 sequences from Papua New Guinea (PNG) from the

210 MalariaGEN P. falciparum Community Project (MalariaGEN Plasmodium falciparum Community

211 Project, 2016) to examine global diversity in clag8, one of the 25 identified genes that has been

212 considered previously as a potential vaccine candidate, and found high nucleotide diversity,

213 Tajima's D, and number of segregating sites in the C-terminal region of clag8. This pattern was

214 consistent when comparing data from parasites collected in Malawi to data from parasites from

215 other regions of the world (Figure 4a). A haplotype network generated using clag8 sequences

216 from multiple geographic areas showed no evidence of regional adaptation (Figure 4b), including

217 low $F_{\text {ST }}$ values between clag8 sequences from Africa, Asia and PNG (Supplementary Table 5).

218 Further analysis of CLAG8 protein sequences show regions with high protein disorder and B-cell

219 epitope sites, especially in the C-terminal region (Supplementary Fig 4). To test our initial

220 hypothesis that immune individuals become ill when infected with parasite antigen alleles that are

221 rarer in the parasite population, we compared the frequency of clag8 haplotypes based on the C-

222 terminal region of the gene in individuals with different levels of immunity and observed that

223 parasites causing illness in individuals in the high immunity group tended to have clag8

224 haplotypes that were lower in frequency compared to individuals in the low immunity group,

225 although significance was borderline (Supplementary Fig 5, $p$-value $=0.099$, Wilcoxon rank sum

226 test). 
medRxiv preprint doi: https://doi.org/10.1101/2020.09.16.20196253; this version posted September 18, 2020. The copyright holder for this preprint (which was not certified by peer review) is the author/funder, who has granted medRxiv a license to display the preprint in perpetuity.

It is made available under a CC-BY-NC-ND 4.0 International license .

a

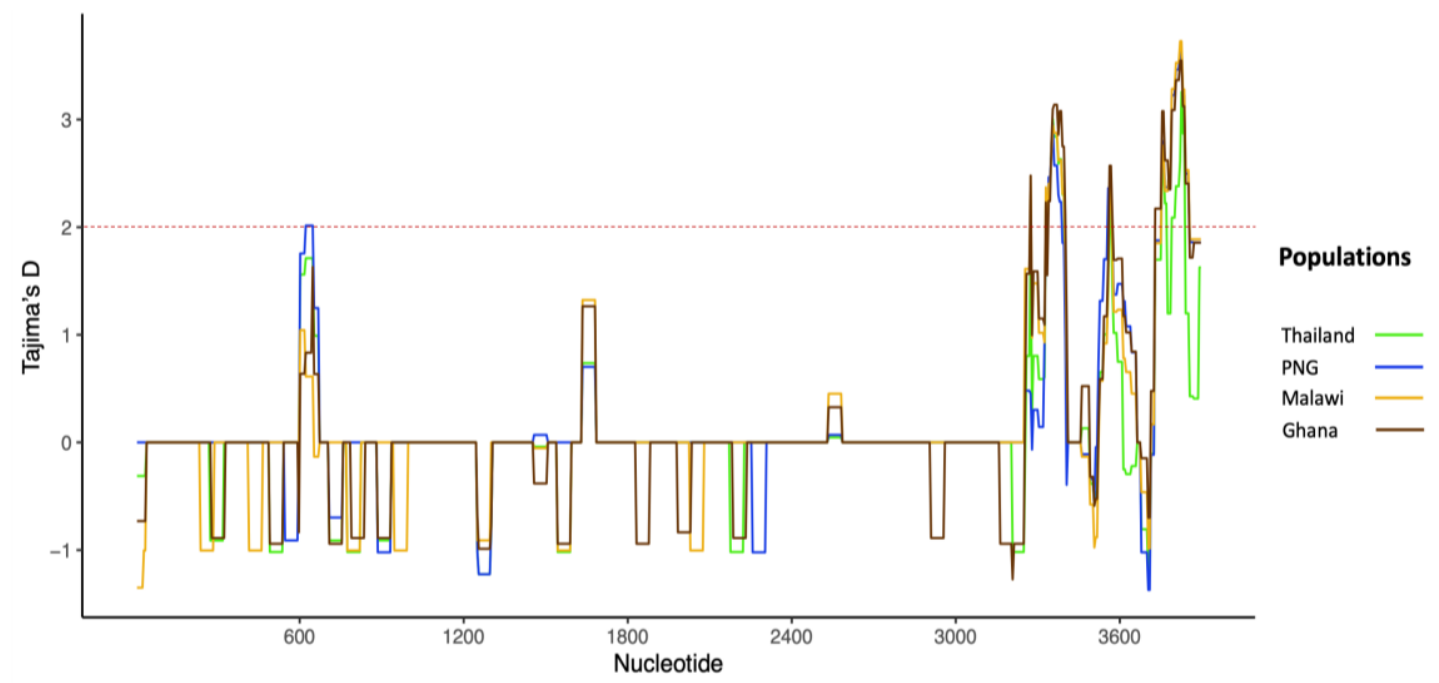

b

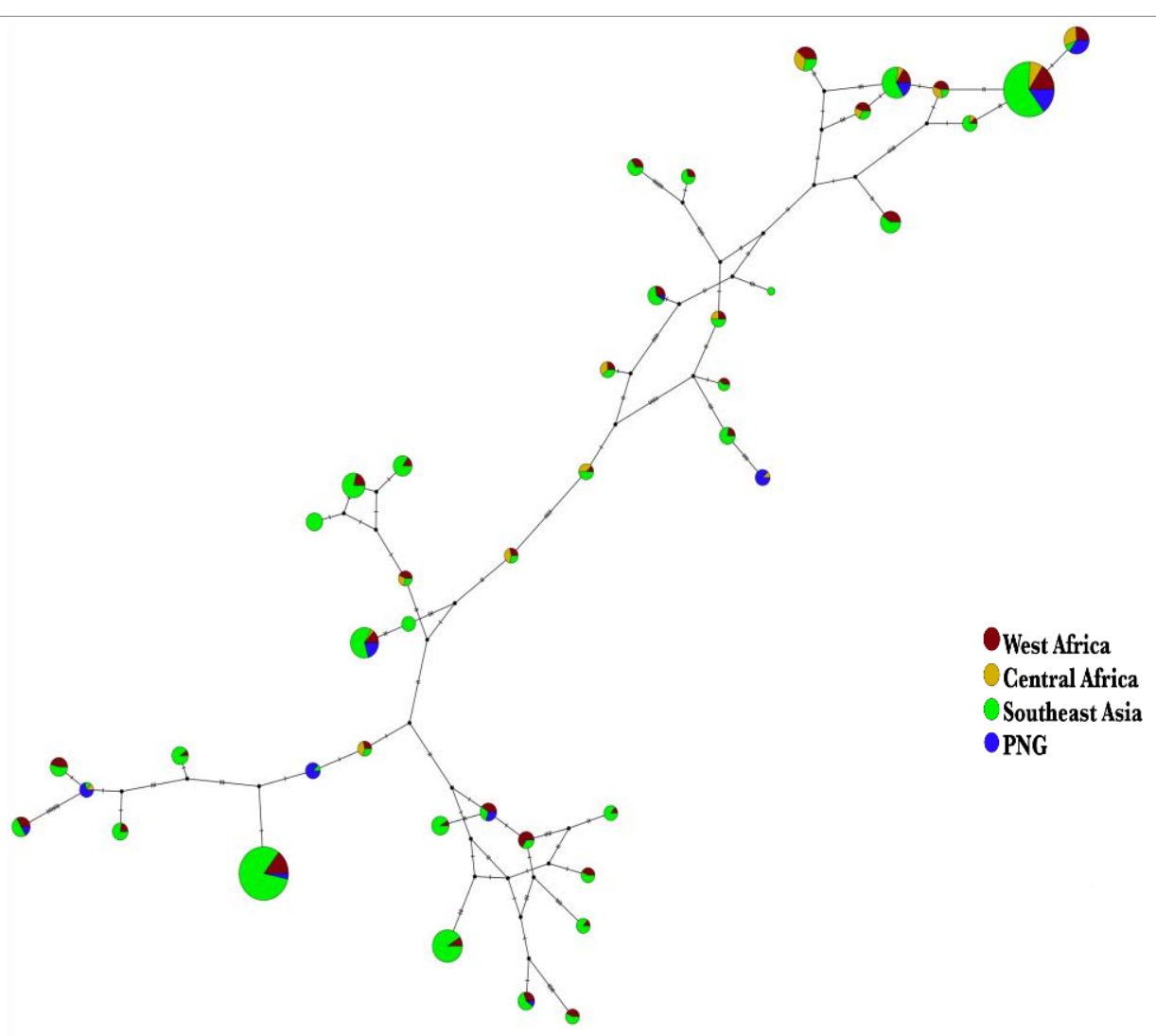

Figure 4. Global diversity of clag8. a) Tajima's D along the clag8 gene in samples from Thailand, PNG, Malawi, and Ghana. The dotted red lines represent a significant positive Tajima's D value $(\geq 2)$, suggestive of balancing selection. b) Haplotype network of clag8 using $P$. falciparum sequence data. 
medRxiv preprint doi: https://doi.org/10.1101/2020.09.16.20196253; this version posted September 18, 2020. The copyright holder for this preprint (which was not certified by peer review) is the author/funder, who has granted medRxiv a license to display the preprint in perpetuity.

It is made available under a CC-BY-NC-ND 4.0 International license .

\section{DISCUSSION}

229 Previous studies have shown evidence of allele-specific acquisition of immunity to $P$. falciparum

230 in single genes or proteins (Cortés et al., 2005; Early et al., 2018; Osier et al., 2008; Polley et al.,

2312007 ; Takala et al., 2007, 2009) that have been identified as potential vaccine antigens based on

232 traditional vaccinology approaches that empirically identify immunogenic proteins. Other studies

233 have performed genome-wide screens to identify genomic signatures of balancing selection but

234 lack individual-level associations with clinical outcomes that might link specific signatures with

235 protective immune responses (Amambua-Ngwa et al., 2012; Mobegi et al., 2014; Mu et al., 2007).

236 In this study, we conducted a genome-wide, individual-level analysis to identify targets of allele-

237 specific immunity to clinical malaria using $P$. falciparum whole genome sequencing data by

238 identifying parasite genes that are genetically differentiated between individuals with different

239 levels of immunity to malaria and genomic regions that are most different in parasites causing

240 illness within the same individual versus between individuals. Twenty-five genes were identified

241 using both analytical approaches and encode likely targets of allele-specific acquired immunity to

242 clinical malaria, including genes thought to be involved in erythrocyte invasion and

243 cytoadherence, among other functions. Examination of global diversity in clag8, a gene whose

244 product has previously been considered as a vaccine candidate, provided evidence of immune

245 selection in the C-terminal region of the gene and did not indicate geographical differences that

246 might be indicative of local adaptation or genetic drift. Consistent with the hypothesis of allele-

247 specific acquisition of immunity, clag8 haplotypes of parasites causing illness in individuals with

248 greater protective immunity were lower in frequency compared to those causing illness in less

249 immune individuals. These findings support the utility of our approach for identification of targets

250 of allele-specific immunity and the further investigation of these 25 loci as potential vaccine

251 candidates.

252 In this study, we estimated the genetic complexity of infections and observed that

253 individuals in the group with higher immunity generally had more complex infections than 
medRxiv preprint doi: https://doi.org/10.1101/2020.09.16.20196253; this version posted September 18, 2020. The copyright holder for this preprint (which was not certified by peer review) is the author/funder, who has granted medRxiv a license to display the preprint in perpetuity.

It is made available under a CC-BY-NC-ND 4.0 International license .

254 individuals with lower immunity. Although not statistically significant, this pattern is broadly

255 consistent with results from other studies that have reported associations between infection

256 complexity and either age and/or risk of disease (Färnert et al., 1999; Takala et al., 2007). The

257 greater complexity of infections in individuals with higher immunity is consistent with the idea that

258 immune individuals are capable of maintaining some parasite clones at a subclinical level and

259 could suggest a possible role of polyclonal infections in maintaining immunity through continuous

260 exposure to different strains (Bereczky et al., 2007; Sondén et al., 2015). In polyclonal infections

261 from our data set, we observed that the predominant clone was more likely to have different alleles

262 than the minor clone at sites identified as potential targets of immunity in our analysis. This finding

263 is consistent with the hypothesis that minority clones are maintained at a subclinical level by

264 acquired immunity, while the predominant clone is able to escape the immune response (because

265 it has unrecognized alleles), resulting in a symptomatic infection. Prior to downstream analysis,

266 infections lacking a predominant clone were excluded to avoid confounding by infection

267 complexity and misclassification of clones likely responsible for disease symptoms. The exclusion

268 of infections lacking a predominant clone led to the removal of a greater proportion of infections

269 from the high immunity group than the low immunity group, which may have resulted in an

270 underestimation of parasite diversity in the high immunity group. However, we do not believe this

271 underestimation impacted our conclusions, as infections within the high immunity group were

272 significantly more diverse at differentiated loci even after exclusion of these highly complex

273 infections.

274 We hypothesized that individuals who have a higher degree of immunity to malaria would

275 have a greater risk of malaria symptoms when infected with parasites having protein variants that

276 are of lower frequency in the local parasite population, owing to their having already acquired

277 immunity to variants encoded by more common alleles. When we estimated nucleotide diversity

278 at differentiated loci in both immunity groups, we found significantly greater diversity in the group

279 with higher immunity compared to the group with lower immunity. This difference in diversity may 
medRxiv preprint doi: https://doi.org/10.1101/2020.09.16.20196253; this version posted September 18, 2020. The copyright holder for this preprint (which was not certified by peer review) is the author/funder, who has granted medRxiv a license to display the preprint in perpetuity.

It is made available under a CC-BY-NC-ND 4.0 International license .

280 reflect the fact that individuals with higher immunity have symptomatic infections with parasite

281 alleles that are rarer in the population and therefore more likely to be different from one another

282 at differentiated loci. This scenario is also supported by our finding that the median frequency of

283 the infecting allele was significantly lower in more immune individuals compared to less immune

284 individuals when examining differentiated loci. These results also demonstrate the importance of

285 accounting for rare alleles in vaccine design, as they may also lead to escape from vaccine-

286 induced immunity.

287 Genome-wide screens for signatures of balancing selection have previously identified 288 some of the 25 genes that we identified in this study, including PF3D7_0710200, clag8 and other 289 genes from the surfin and phist multigene families (Amambua-Ngwa et al., 2012; Mobegi et al., 290 2014; Mu et al., 2007). PF3D7_0710200, a gene encoding a conserved protein of unknown 291 function, was identified by three separate studies as a potential immune target (Amambua-Ngwa 292 et al., 2012; Mobegi et al., 2014; Mu et al., 2007); however, little is known about the function of 293 this protein. Indeed, 11 of the 25 genes (44\%) identified in this study encode for proteins of 294 unknown function, highlighting the importance of further genetic screens to determine the role of 295 such genes, which make up $\sim 35 \%$ of the parasite genome (Sexton et al., 2019). A recent study 296 has suggested that most genes involved in host-parasite interactions, including many known 297 antigens, are non-essential (Zhang et al., 2018); however, eight of the 25 genes identified in this 298 study would be considered essential genes, based on their low mutagenesis index score (Zhang 299 et al., 2018) (Supplementary Table 4). Such essential genes may be attractive vaccine targets as 300 there may be less redundancy in function that would allow the parasite to adapt and escape 301 vaccine-induced inhibition.

302 As a proof of concept of the utility of our approach for identifying targets of allele-specific 303 immunity, we further examined the global diversity of one of the 25 identified genes, clag8, which 304 has previously been considered as a malaria vaccine candidate. clag8 belongs to the clag 305 multigene family and is one of the least studied genes in the clag family. clag8 is highly expressed 
medRxiv preprint doi: https://doi.org/10.1101/2020.09.16.20196253; this version posted September 18, 2020. The copyright holder for this preprint (which was not certified by peer review) is the author/funder, who has granted medRxiv a license to display the preprint in perpetuity.

It is made available under a CC-BY-NC-ND 4.0 International license .

306

307

308

309

310

311

312

313

314

315

316

317

318

319

320

321

322

323

324

325

326

327

328

329

330

331

during the first few hours following erythrocyte invasion (early ring stage), displays decreased expression from 5 hours to 35 hours post invasion, and then increased expression during the schizont stage (Toenhake et al., 2018). It is thought to be part of the RhopH complex, formed by the members of $r h o p h 1 /$ clag gene families. The RhopH complex is an erythrocyte-binding protein complex inside the rhoptry and has been suggested to play an important role in establishment of the parasitophorous vacuole (Iriko et al., 2008; Kaneko et al., 2005; Sam-Yellowe \& Perkins, 1991). Previous studies have reported evidence of positive diversifying selection in this gene, with high nucleotide diversity and a high proportion of non-synonymous substitutions per site $\left(d_{N}\right)$ (Iriko et al., 2008). Our global analysis of clag8 diversity displayed high nucleotide diversity and Tajima's D values in the C-terminal region of the gene, as well as evidence of high protein disorder and predicted B-cell epitopes in the C-terminal region of the protein, suggesting that it is likely to be immunogenic (Guy et al., 2015, p. 20). These results were consistent in all the countries included in the dataset, which represented parasite isolates from three major malaria endemic regions (Pf3k Pilot Data Release 5 / MalariaGEN, n.d.). Additionally, clag8 haplotypes displayed no evidence of geographical adaptation, with major haplotypes being observed in all geographic areas, and seemed to cluster into three main groups. Further studies to identify functional epitopes within the protein and potential cross-reactivity are necessary to determine whether related haplotypes can be grouped into serotypes for the purpose of designing a broadly protective vaccine. At an individual level, and in support of our overarching hypothesis, individuals with higher immunity to malaria were infected with clag8 haplotypes that were less frequent compared to the clag8 haplotypes infecting individuals with lower immunity.

It is noteworthy that our combined list of genes based on both analytical approaches did not include leading blood stage vaccine candidates such as AMA1 and the MSPs, although some of these genes were identified in a single approach. Using a protein microarray, Crompton et al. found that antibody responses to leading vaccine candidates, such as AMA1, MSP1, and MSP2, did not distinguish individuals who were protected from clinical infection versus those who were 
medRxiv preprint doi: https://doi.org/10.1101/2020.09.16.20196253; this version posted September 18, 2020. The copyright holder for this preprint (which was not certified by peer review) is the author/funder, who has granted medRxiv a license to display the preprint in perpetuity.

It is made available under a CC-BY-NC-ND 4.0 International license .

332 not in a cohort of individuals from Mali (Crompton et al., 2010), suggesting the possibility that

333 responses to these proteins are not the primary drivers of clinical immunity. Other studies

334 (Akpogheneta et al., 2008; Kinyanjui et al., 2007; Takala et al., 2009) have supported the

335 hypothesis that responses to antigens such as AMA1 contribute to allele-specific clinical immunity

336 but may be short-lived. In our analyses, infection pairs within an individual were not necessarily

337 consecutive infections, with the time between infections ranging from 27 to 696 days. Although

338 we did not see a significant correlation between the proportion of allele mismatches and the

339 number of days between infections in a pair, it is possible that we could have failed to identify

340 antigens involved in allele-specific acquisition of immunity that elicit short-lived immune

341 responses. Studies with larger sample size would likely be required to distinguish antigens that

342 have different antibody kinetics.

343 In addition, analyses in this study included only the core genome, owing to our use of

344 selective whole genome amplification to enrich for parasite DNA prior to sequencing, which has

345 been shown to result in poor sequencing coverage in the telomeric and centromeric regions

346 (Oyola et al., 2016; Shah et al., 2020). Limiting analysis to the core genome could have prevented

347 us from identifying members of multigene families that may be important for development of

348 immunity to clinical malaria, as many of these genes are located in these low-coverage regions

349 of the genome. However, because multigene families have been implicated in severe malaria, it

350 is possible that immunity to these diverse antigens may be more relevant to preventing severe

351 rather than uncomplicated malaria.

352 Here, we describe a promising genome-wide, individual-level approach to identify potential

353 targets of allele-specific immunity to clinical malaria. Using this approach, we identified 25 genes,

354 many of unknown function, that encode proteins that can be further characterized for their

355 potential as candidates for a multivalent subunit malaria vaccine. Although further immunological

356 validation will be necessary to confirm that the patterns observed in this study result from allele- 
medRxiv preprint doi: https://doi.org/10.1101/2020.09.16.20196253; this version posted September 18, 2020. The copyright holder for this preprint (which was not certified by peer review) is the author/funder, who has granted medRxiv a license to display the preprint in perpetuity.

It is made available under a CC-BY-NC-ND 4.0 International license .

357 specific immune responses, our results support the utility of this genomic epidemiology approach

358 to identify new vaccine candidate antigens.

359

360 METHODS

361 Study design and samples

362 Parasite isolates were collected from participants in a longitudinal cohort study conducted in a 363 rural area in southern Malawi. Details about the participants and study procedures have been 364 described previously by Buchwald et al (Buchwald, Sixpence, et al., 2019). The data analyzed in 365 this study were generated from red blood cell pellets collected from symptomatic, uncomplicated 366 malaria infections. Samples were collected under protocols approved by the ethics committees at 367 the College of Medicine in Blantyre, Malawi, and the University of Maryland, Baltimore, and with 368 the informed consent of the participants or their guardians. The median parasitemia of the 369 sampled infections as determined by microscopy was 21,960 parasites $/ \mu \mathrm{L}$ and ranged from 0 370 parasites $/ \mu \mathrm{L}$ (but positive by a rapid diagnostic test) to 241,260 parasites $/ \mu \mathrm{L}$. All samples were

371 confirmed to be positive for $P$. falciparum via PCR. To ensure only independent infections were

372 included in the analysis, infections within an individual separated by $<14$ days were excluded.

373 DNA from red blood cell pellets was extracted using the method of Zainabadi et al (Zainabadi et 374 al., 2017). Extracted DNA was enriched for parasite DNA using an optimized selective whole 375 genome amplification approach described by Shah et al (Shah et al., 2020).

377 Whole genome sequencing

378 Genomic DNA libraries were constructed for sequencing using the KAPA Library Preparation Kit 379 (Kapa Biosystems, Woburn, MA). DNA ( $\geq 200 \eta \mathrm{g}$ ) was fragmented with the Covaris E210 to 200 380 bp. Libraries were prepared using a modified version of the manufacturer's protocol. The DNA 381 was purified between enzymatic reactions and library size selection was performed with AMPure 
medRxiv preprint doi: https://doi.org/10.1101/2020.09.16.20196253; this version posted September 18, 2020. The copyright holder for this preprint (which was not certified by peer review) is the author/funder, who has granted medRxiv a license to display the preprint in perpetuity.

It is made available under a CC-BY-NC-ND 4.0 International license .

382 XT beads. Libraries were assessed for concentration and fragment size using the DNA High

383 Sensitivity Assay on the LabChip GX (Perkin Elmer, Waltham, MA). Library concentrations were

384 also assessed by QPCR using the KAPA Library Quantification Kit. Libraries were pooled and 385 subsequently sequenced on an Illumina HiSeq 4000 (Illumina, San Diego, CA) to generate 150

386 bp paired-end reads. Sequencing data are available at NCBI under the project numbers and 387 accession numbers listed in Supplementary Table 6.

\section{Read mapping and SNP Calling}

390 Sequencing data were analyzed by mapping raw fastq files to the 3D7 reference genome using 391 Bowtie2 (Langmead \& Salzberg, 2012). Binary Alignment Map (BAM) files were processed 392 following the GATK Best Practices workflow to obtain analysis-ready reads (DePristo et al., 2011; 393 Van der Auwera et al., 2013). Bedtools (Quinlan \& Hall, 2010) was used to generate coverage 394 and depth estimates from the processed reads, and the GATK Best Practices workflow was 395 followed for variant calling (DePristo et al., 2011; Van der Auwera et al., 2013). Haplotype Caller 396 was used to create genomic variant call format (GVCF) files for each sample and joint SNP Calling 397 was performed (GATK v3.7). Variants were removed if they met the following filtering criteria: 398 variant confidence/quality by depth $(\mathrm{QD})<2.0$, strand bias $(\mathrm{FS})>60.0$, root mean square of the 399 mapping quality $(\mathrm{MQ})<40.0$, mapping quality rank sum (MQRankSum) $<-12.5$, read position 400 rank sum (ReadPosRankSum) $<-8.0$, quality (QUAL) $<50$. Variant sites with $>20 \%$ missing 401 genotypes and samples with $>30 \%$ missing data were additionally removed using vcftools. 402 Variants were also removed if the minor allele was not present in at least two samples. Only the 403 core genome was used for further analysis. The median percentage of the genome covered with 404 at least 20 reads was $88.87 \%$ (Shah et al., 2020).

405

406 Definition of immune status 
medRxiv preprint doi: https://doi.org/10.1101/2020.09.16.20196253; this version posted September 18, 2020. The copyright holder for this preprint (which was not certified by peer review) is the author/funder, who has granted medRxiv a license to display the preprint in perpetuity.

It is made available under a CC-BY-NC-ND 4.0 International license .

407 The degree of immunity to clinical malaria was defined based on the proportion of symptomatic

408 infections out of all $P$. falciparum infections experienced by each study participant over the course

409 of the two-year study. To account for exposure, individuals with less than five total infections,

410 including symptomatic and asymptomatic infections, were excluded from the analysis. The

411 median proportion of symptomatic infections was used as the cutoff to categorize individuals into

412 higher and lower immunity groups.

413

\section{Complexity of infection and genetic differentiation}

415 Only one infection from each individual was included in comparisons between high a low immunity

416 groups. Infections were selected based on proximity to the median of the distribution of sampling

417 dates to reduce temporal variability. DEploid-IBD (Zhu et al., 2017) was used to estimate the

418 proportion of each clone within an infection. Infections without a predominant clone (i.e., where

419 the majority clone had a frequency $<60 \%$ within the infection) were defined as complex infections

420 and were excluded from downstream analysis. For the remaining samples, the major allele was

421 called at heterozygous positions if the allele was supported by $\geq 70 \%$ of reads; otherwise, the

422 genotype was coded as missing. A Wilcoxon rank sum test was used to assess differences in the

423 frequency of the majority clone in infections from the two immunity groups.

424 Vcftools (Danecek et al., 2011) was used to estimate Weir and Cockerham $F_{\text {ST }}$ in variable

425 non-synonymous, bi-allelic sites. Significance was determined using 10,000 permutations, where

426 the observed population was resampled without replacement. Nucleotide diversity at significantly

427 differentiated sites was estimated using vcftools (Danecek et al., 2011). PlasmoDB (v44)

428 (PlasmoDB: The Plasmodium Genomics Resource, n.d.) was used to identify genes containing 429 differentiated SNPs.

430 In all polyclonal infections, the major and minor clones (defined by clone frequencies

431 obtained from DEploid-IBD (Zhu et al., 2017)) were compared, provided clone frequency was less

432 than $80 \%$ and greater than $10 \%(n=23)$. At each non-synonymous site, the proportion of samples 
medRxiv preprint doi: https://doi.org/10.1101/2020.09.16.20196253; this version posted September 18, 2020. The copyright holder for this preprint (which was not certified by peer review) is the author/funder, who has granted medRxiv a license to display the preprint in perpetuity.

It is made available under a CC-BY-NC-ND 4.0 International license .

433 with mismatched alleles from major and minor clones was estimated. The proportion of

434 mismatches was then compared between significantly differentiated sites and all remaining

435 variable sites from the genome. The $p$-value was estimated by conducting a Wilcoxon rank sum

436 test to determine if there is a significant difference in mismatches between clones at different sites

437 versus remaining genome-wide variable sites.

439 Paired infection analysis

440 Individuals with parasite whole genome sequence data from at least two symptomatic infections

441 occurring at least 14 days apart were included in the comparison of infections occurring within the

442 same host to infections occurring in different hosts. Multi-allelic sites were included in the analysis

443 of paired infections, in contrast to analyses of genetic differentiation. The 'within' group included

444 all pairs of parasites collected at different time points from the same individual. The 'between

445 group', included all pairs of parasites from different individuals. A total of 116 samples were

446 included in this study. The within group contained 124 pairs of samples and the between group

447 contained 6546 pairs of samples. For all pairs, the allelic state was compared at each site and

448 the proportion of pairs with non-matching allelic states was estimated by site (illustrated in Figure

449 3). The difference between the within group and the between group was calculated by subtracting

450 the proportion of pairs with non-matching allelic states for each site. The $p$-value was estimated

451 by conducting a one-sided z-test using the difference in proportion of mismatched alleles between

452 the two groups. PlasmoDB (PlasmoDB: The Plasmodium Genomics Resource, n.d.) was used

453 to identify genes containing the SNPs of interest.

454

\section{Global diversity in clag8}

456 The MalariaGEN Pf3K project release 5.1 data(Pf3k Pilot Data Release 5 / MalariaGEN, n.d.) was

457 used to estimate global diversity in these genes identified in this study. The Pf3K dataset includes

458 whole genome sequencing data from 2,512 samples collected in multiple locations in Asia and 
medRxiv preprint doi: https://doi.org/10.1101/2020.09.16.20196253; this version posted September 18, 2020. The copyright holder for this preprint (which was not certified by peer review) is the author/funder, who has granted medRxiv a license to display the preprint in perpetuity.

It is made available under a CC-BY-NC-ND 4.0 International license .

459

460

461

462

463

464

465

466

467

468

469

470

471

\section{Acknowledgements}

473 We thank the participants in the Mfera Cohort Study. We would like to thank Biraj Shrestha and

474 Gillian Mbambo for their assistance with sample processing. We would also like to acknowledge

475 Timothy D. O'Connor, Michael P. Cummings and Alexis Boleda for their valuable input and

476 suggestions, and Terrie Taylor for her role in leading the Malawi International Center of

477 Excellence for Malaria Research. This work was supported by funding from the following awards

478 granted by the National Institutes of Health: R01Al101713, R01Al125579, R01Al141900,

479 U19Al110820, K24Al114996, and the Malawi International Center of Excellence for Malaria

480 Research U19AI089683.

481

\section{Author Contributions}

483 Conceived and designed the study: ZS, MKL, JCS and ST-H. Collected and provided the 484 samples: AGB, KBS, DPM, and MKL. Sequence processing and variant calling: ZS, KAM, and 
JCS. Analyzed the data: ZS, MTN, KAM, AD, DS, AEB, and ST-H. Interpreted the results: ZS, MA, AO, KBS, DS, AEB, MKL, JCS, and ST-H. Wrote the manuscript: ZS and ST-H. All authors have read and had the opportunity to comment on the manuscript.

\section{Competing Interests}

490 The authors declare no competing interests.

\section{References}

493 Akpogheneta, O. J., Duah, N. O., Tetteh, K. K. A., Dunyo, S., Lanar, D. E., Pinder, M., \& Conway, D. J. (2008). Duration of Naturally Acquired Antibody Responses to BloodStage Plasmodium falciparum Is Age Dependent and Antigen Specific. Infection and

Amambua-Ngwa, A., Tetteh, K. K. A., Manske, M., Gomez-Escobar, N., Stewart, L. B., O., Jallow, M., Campino, S., Maclnnis, B., Kwiatkowski, D. P., \& Conway, D. J. (2012). Population Genomic Scan for Candidate Signatures of Balancing Selection to Guide Antigen Characterization in Malaria Parasites. PLoS Genetics, 8(11). https://doi.org/10.1371/journal.pgen.1002992

Barry, A. E., Trieu, A., Fowkes, F. J. I., Pablo, J., Kalantari-Dehaghi, M., Jasinskas, A., Tan, X., Kayala, M. A., Tavul, L., Siba, P. M., Day, K. P., Baldi, P., Felgner, P. L., \& Doolan, D. L.

508 Bejon, P., Williams, T. N., Liljander, A., Noor, A. M., Wambua, J., Ogada, E., Olotu, A., Osier, F. (2011). The Stability and Complexity of Antibody Responses to the Major Surface Antigen of Plasmodium falciparum Are Associated with Age in a Malaria Endemic Area. Molecular \& Cellular Proteomics, 10(11). https://doi.org/10.1074/mcp.M111.008326 H. A., Hay, S. I., Färnert, A., \& Marsh, K. (2010). Stable and unstable malaria hotspots in 
longitudinal cohort studies in Kenya. PLoS Medicine, 7(7), e1000304. https://doi.org/10.1371/journal.pmed.1000304

512 Bereczky, S., Liljander, A., Rooth, I., Faraja, L., Granath, F., Montgomery, S. M., \& Färnert, A. 513 (2007). Multiclonal asymptomatic Plasmodium falciparum infections predict a reduced risk of malaria disease in a Tanzanian population. Microbes and Infection, 9(1), 103-

516 Bhatia, G., Patterson, N., Sankararaman, S., \& Price, A. L. (2013). Estimating and interpreting FST: The impact of rare variants. Genome Research, 23(9), 1514-1521.

519 Bousema, T., Drakeley, C., Gesase, S., Hashim, R., Magesa, S., Mosha, F., Otieno, S., Carneiro, I., Cox, J., Msuya, E., Kleinschmidt, I., Maxwell, C., Greenwood, B., Riley, E.,

524 Buchwald, A. G., Sixpence, A., Chimenya, M., Damson, M., Sorkin, J. D., Wilson, M. L., Seydel, K., Hochman, S., Mathanga, D. P., Taylor, T. E., \& Laufer, M. K. (2019). Clinical Sauerwein, R., Chandramohan, D., \& Gosling, R. (2010). Identification of Hot Spots of

Buchwald, A. G., Sorkin, J. D., Sixpence, A., Chimenya, M., Damson, M., Wilson, M. L., Seydel, Implications of Asymptomatic Plasmodium falciparum Infections in Malawi. Clinical Infectious Diseases: An Official Publication of the Infectious Diseases Society of K., Hochman, S., Mathanga, D., Taylor, T. E., \& Laufer, M. K. (2019). Association Between Age and Plasmodium falciparum Infection Dynamics. American Journal of Epidemiology, 188(1), 169-176. https://doi.org/10.1093/aje/kwy213

Clark, T. D., Greenhouse, B., Njama-Meya, D., Nzarubara, B., Maiteki-Sebuguzi, C., Staedke, S. G., Seto, E., Kamya, M. R., Rosenthal, P. J., \& Dorsey, G. (2008). Factors 
determining the heterogeneity of malaria incidence in children in Kampala, Uganda. The Journal of Infectious Diseases, 198(3), 393-400. https://doi.org/10.1086/589778

537 Clement, M., Snell, Q., Walke, P., Posada, D., \& Crandall, K. (2002). TCS: Estimating gene genealogies. Proceedings 16th International Parallel and Distributed Processing Symposium, 7 pp. https://doi.org/10.1109/IPDPS.2002.1016585

Cortés, A., Mellombo, M., Masciantonio, R., Murphy, V. J., Reeder, J. C., \& Anders, R. F. (2005). Allele specificity of naturally acquired antibody responses against Plasmodium falciparum apical membrane antigen 1. Infection and Immunity, 73(1), 422-430.

Cowman, A. F., Healer, J., Marapana, D., \& Marsh, K. (2016). Malaria: Biology and Disease. Cell, 167(3), 610-624. https://doi.org/10.1016/j.cell.2016.07.055

Crompton, P. D., Kayala, M. A., Traore, B., Kayentao, K., Ongoiba, A., Weiss, G. E., Molina, D. M., Burk, C. R., Waisberg, M., Jasinskas, A., Tan, X., Doumbo, S., Doumtabe, D., Kone, Y., Narum, D. L., Liang, X., Doumbo, O. K., Miller, L. H., Doolan, D. L., ... Pierce, S. K. (2010). A prospective analysis of the Ab response to Plasmodium falciparum before and

552 Danecek, P., Auton, A., Abecasis, G., Albers, C. A., Banks, E., DePristo, M. A., Handsaker, R. after a malaria season by protein microarray. Proceedings of the National Academy of 
561 Dutta, S., Lee, S. Y., Batchelor, A. H., \& Lanar, D. E. (2007). Structural basis of antigenic escape of a malaria vaccine candidate. Proceedings of the National Academy of Sciences, 104(30), 12488-12493. https://doi.org/10.1073/pnas.0701464104

564 Early, A. M., Lievens, M., Maclnnis, B. L., Ockenhouse, C. F., Volkman, S. K., Adjei, S., Agbenyega, T., Ansong, D., Gondi, S., Greenwood, B., Hamel, M., Odero, C., Otieno, K., Otieno, W., Owusu-Agyei, S., Asante, K. P., Sorgho, H., Tina, L., Tinto, H., ... Neafsey,

Egan, A. F., Morris, J., Barnish, G., Allen, S., Greenwood, B. M., Kaslow, D. C., Holder, A. A., \& Riley, E. M. (1996). Clinical immunity to Plasmodium falciparum malaria is associated with serum antibodies to the 19-kDa C-terminal fragment of the merozoite surface antigen, PfMSP-1. The Journal of Infectious Diseases, 173(3), 765-769.

Elissa, N., Migot-Nabias, F., Luty, A., Renaut, A., Touré, F., Vaillant, M., Lawoko, M., Yangari, P., Mayombo, J., Lekoulou, F., Tshipamba, P., Moukagni, R., Millet, P., \& Deloron, P. (2003). Relationship between entomological inoculation rate, Plasmodium falciparum prevalence rate, and incidence of malaria attack in rural Gabon. Acta Tropica, 85(3),

Färnert, A., Rooth, I., Svensson, Å., Snounou, G., \& Björkman, A. (1999). Complexity of Plasmodium falciparum Infections Is Consistent over Time and Protects against Clinical Disease in Tanzanian Children. The Journal of Infectious Diseases, 179(4), 989-995.

584 Gardner, M. J., Hall, N., Fung, E., White, O., Berriman, M., Hyman, R. W., Carlton, J. M., Pain, A., Nelson, K. E., Bowman, S., Paulsen, I. T., James, K., Eisen, J. A., Rutherford, K., Salzberg, S. L., Craig, A., Kyes, S., Chan, M.-S., Nene, V., ... Barrell, B. (2002). 
Genome sequence of the human malaria parasite Plasmodium falciparum. Nature, 419(6906), 498-511. https://doi.org/10.1038/nature01097

Gaudart, J., Poudiougou, B., Dicko, A., Ranque, S., Toure, O., Sagara, I., Diallo, M., Diawara,

Gupta, A., Thiruvengadam, G., \& Desai, S. A. (2015). The conserved clag multigene family of malaria parasites: Essential roles in host-pathogen interaction. Drug Resistance Updates : Reviews and Commentaries in Antimicrobial and Anticancer Chemotherapy,

Guy, A. J., Irani, V., MacRaild, C. A., Anders, R. F., Norton, R. S., Beeson, J. G., Richards, J. S., \& Ramsland, P. A. (2015). Insights into the Immunological Properties of Intrinsically Disordered Malaria Proteins Using Proteome Scale Predictions. PLOS ONE, 10(10), e0141729. https://doi.org/10.1371/journal.pone.0141729

Holt, D. C., Gardiner, D. L., Thomas, E. A., Mayo, M., Bourke, P. F., Sutherland, C. J., Carter, R., Myers, G., Kemp, D. J., \& Trenholme, K. R. (1999). The cytoadherence linked asexual gene family of Plasmodium falciparum: Are there roles other than cytoadherence? International Journal for Parasitology, 29(6), 939-944. https://doi.org/10.1016/s0020-7519(99)00046-6

Iriko, H., Kaneko, O., Otsuki, H., Tsuboi, T., Su, X., Tanabe, K., \& Torii, M. (2008). Diversity and

610 Kaneko, O., Lim, B. Y. S. Y., Iriko, H., Ling, I. T., Otsuki, H., Grainger, M., Tsuboi, T., Adams, J. H., Mattei, D., Holder, A. A., \& Torii, M. (2005). Apical expression of three RhopH1/Clag proteins as components of the Plasmodium falciparum RhopH complex. Molecular and 
Kang, S. Y., Battle, K. E., Gibson, H. S., Cooper, L. V., Maxwell, K., Kamya, M., Lindsay, S. W.,

Kinyanjui, S. M., Conway, D. J., Lanar, D. E., \& Marsh, K. (2007). IgG antibody responses to Plasmodium falciparum merozoite antigens in Kenyan children have a short half-life. Malaria Journal, 6, 82. https://doi.org/10.1186/1475-2875-6-82

Krzyczmonik, K., Świtnicki, M., \& Kaczanowski, S. (2012). Analysis of immunogenicity of different protein groups from malaria parasite Plasmodium falciparum. Infection, Genetics and Evolution, 12(8), 1911-1916. https://doi.org/10.1016/j.meegid.2012.07.023 Methods, 9(4), 357-359. https://doi.org/10.1038/nmeth.1923

MalariaGEN Plasmodium falciparum Community Project. (2016). Genomic epidemiology of artemisinin resistant malaria. ELife, 5, e08714. https://doi.org/10.7554/eLife.08714 Immunology, 28(1-2), 51-60. https://doi.org/10.1111/j.1365-3024.2006.00808.x Plasmodium falciparum merozoite surface protein 2 is strongly associated with a Maclnnis, B., Aspeling-Jones, H., Murray, L., Clark, T. G., Kwiatkowski, D. P., \& Conway, D. J. (2014). Genome-wide analysis of selection on the malaria parasite 
Plasmodium falciparum in West African populations of differing infection endemicity. Molecular Biology and Evolution, 31(6), 1490-1499. https://doi.org/10.1093/molbev/msu106

642 Mu, J., Awadalla, P., Duan, J., McGee, K. M., Keebler, J., Seydel, K., McVean, G. A. T., \& Su, X. (2007). Genome-wide variation and identification of vaccine targets in the

Osier, F. H. A., Fegan, G., Polley, S. D., Murungi, L., Verra, F., Tetteh, K. K. A., Lowe, B., Mwangi, T., Bull, P. C., Thomas, A. W., Cavanagh, D. R., McBride, J. S., Lanar, D. E.,

652 Ouattara, A., Barry, A. E., Dutta, S., Remarque, E. J., Beeson, J. G., \& Plowe, C. V. (2015). Designing malaria vaccines to circumvent antigen variability. Vaccine, 33(52), 7506-

Ouattara, A., Takala-Harrison, S., Thera, M. A., Coulibaly, D., Niangaly, A., Saye, R., Tolo, Y., Mackinnon, M. J., Conway, D. J., \& Marsh, K. (2008). Breadth and magnitude of antibody responses to multiple Plasmodium falciparum merozoite antigens are associated with protection from clinical malaria. Infection and Immunity, 76(5), 2240Dutta, S., Heppner, D. G., Soisson, L., Diggs, C. L., Vekemans, J., Cohen, J., Blackwelder, W. C., Dube, T., Laurens, M. B., Doumbo, O. K., \& Plowe, C. V. (2013). Molecular basis of allele-specific efficacy of a blood-stage malaria vaccine: Vaccine development implications. The Journal of Infectious Diseases, 207(3), 511-519. https://doi.org/10.1093/infdis/jis709

Oyola, S. O., Ariani, C. V., Hamilton, W. L., Kekre, M., Amenga-Etego, L. N., Ghansah, A., Rutledge, G. G., Redmond, S., Manske, M., Jyothi, D., Jacob, C. G., Otto, T. D., Rockett, K., Newbold, C. I., Berriman, M., \& Kwiatkowski, D. P. (2016). Whole genome 

genome amplification. Malaria Journal, 15. https://doi.org/10.1186/s12936-016-1641-7

666 Perraut, R., Varela, M.-L., Joos, C., Diouf, B., Sokhna, C., Mbengue, B., Tall, A., Loucoubar, C., Touré, A., \& Mercereau-Puijalon, O. (2017). Association of antibodies to Plasmodium

670 Pf3k pilot data release 5 / MalariaGEN. (n.d.). Retrieved December 23, 2019, from https://www.malariagen.net/data/pf3K-5

672 PlasmoDB: a functional genomic database for malaria parasites. - PubMed-NCBI. (n.d.). Retrieved February 18, 2020, from https://www.ncbi.nlm.nih.gov/pubmed?cmd=search\&term=18957442

PlasmoDB: The Plasmodium Genomics Resource. (n.d.). Retrieved May 1, 2018, from http://plasmodb.org/plasmo/

677 Polley, S. D., Tetteh, K. K. A., Lloyd, J. M., Akpogheneta, O. J., Greenwood, B. M., Bojang, K. A., \& Conway, D. J. (2007). Plasmodium falciparum Merozoite Surface Protein 3 Is a Target of Allele-Specific Immunity and Alleles Are Maintained by Natural Selection. The Journal of Infectious Diseases, 195(2), 279-287. https://doi.org/10.1086/509806

Popart: Full-feature software for haplotype network construction—Leigh-2015-Methods in Ecology and Evolution-Wiley Online Library. (n.d.). Retrieved February 4, 2020, from https://besjournals.onlinelibrary.wiley.com/doi/full/10.1111/2041-210X.12410

684 Portugal, S., Pierce, S. K., \& Crompton, P. D. (2013). Young Lives Lost as B Cells Falter: What We Are Learning About Antibody Responses in Malaria. The Journal of Immunology,

687 Proellocks, N. I., Herrmann, S., Buckingham, D. W., Hanssen, E., Hodges, E. K., Elsworth, B., 688 Morahan, B. J., Coppel, R. L., \& Cooke, B. M. (2014). A lysine-rich membraneassociated PHISTb protein involved in alteration of the cytoadhesive properties of 
medRxiv preprint doi: https://doi.org/10.1101/2020.09.16.20196253; this version posted September 18, 2020. The copyright holder for this preprint (which was not certified by peer review) is the author/funder, who has granted medRxiv a license to display the preprint in perpetuity.

It is made available under a CC-BY-NC-ND 4.0 International license .

690

691

692

693

694

695

696

697

698

699

700

701

702

703

704

705

706

707

708

709

710

711

712

713

714

715

Plasmodium falciparum-infected red blood cells. FASEB Journal: Official Publication of the Federation of American Societies for Experimental Biology, 28(7), 3103-3113. https://doi.org/10.1096/fj.14-250399

Quinlan, A. R., \& Hall, I. M. (2010). BEDTools: A flexible suite of utilities for comparing genomic features. Bioinformatics, 26(6), 841-842. https://doi.org/10.1093/bioinformatics/btq033

Quintana, M. D. P., Ch'ng, J.-H., Zandian, A., Imam, M., Hultenby, K., Theisen, M., Nilsson, P., Qundos, U., Moll, K., Chan, S., \& Wahlgren, M. (2018). SURGE complex of Plasmodium falciparum in the rhoptry-neck (SURFIN4.2-RON4-GLURP) contributes to merozoite invasion. PloS One, 13(8), e0201669. https://doi.org/10.1371/journal.pone.0201669

Rozas, J., Ferrer-Mata, A., Sánchez-DelBarrio, J. C., Guirao-Rico, S., Librado, P., RamosOnsins, S. E., \& Sánchez-Gracia, A. (2017). DnaSP 6: DNA Sequence Polymorphism Analysis of Large Data Sets. Molecular Biology and Evolution, 34(12), 3299-3302. https://doi.org/10.1093/molbev/msx248

Ryg-Cornejo, V., Ly, A., \& Hansen, D. S. (2016). Immunological processes underlying the slow acquisition of humoral immunity to malaria. Parasitology, 143(2), 199-207. https://doi.org/10.1017/S0031182015001705

Sam-Yellowe, T. Y., \& Perkins, M. E. (1991). Interaction of the 140/130/110 kDa rhoptry protein complex of Plasmodium falciparum with the erythrocyte membrane and liposomes. Experimental Parasitology, 73(2), 161-171. https://doi.org/10.1016/00144894(91)90019-S

Sexton, A. E., Doerig, C., Creek, D. J., \& Carvalho, T. G. (2019). Post-Genomic Approaches to Understanding Malaria Parasite Biology: Linking Genes to Biological Functions. ACS Infectious Diseases, 5(8), 1269-1278. https://doi.org/10.1021/acsinfecdis.9b00093

Shah, Z., Adams, M., Moser, K. A., Shrestha, B., Stucke, E. M., Laufer, M. K., Serre, D., Silva, J. C., \& Takala-Harrison, S. (2020). Optimization of parasite DNA enrichment approaches to generate whole genome sequencing data for Plasmodium falciparum 
from low parasitaemia samples. Malaria Journal, 19(1), 135. https://doi.org/10.1186/s12936-020-03195-8

718 Sondén, K., Doumbo, S., Hammar, U., Vafa Homann, M., Ongoiba, A., Traoré, B., Bottai, M., Crompton, P. D., \& Färnert, A. (2015). Asymptomatic Multiclonal Plasmodium falciparum Infections Carried Through the Dry Season Predict Protection Against Subsequent Clinical Malaria. The Journal of Infectious Diseases, 212(4), 608-616.

723 Takala, S. L., Coulibaly, D., Thera, M. A., Batchelor, A. H., Cummings, M. P., Escalante, A. A.,

724 Ouattara, A., Traoré, K., Niangaly, A., Djimdé, A. A., Doumbo, O. K., \& Plowe, C. V. (2009). Extreme Polymorphism in a Vaccine Antigen and Risk of Clinical Malaria: Implications for Vaccine Development. Science Translational Medicine, 1(2), 2ra5-2ra5.

728 Takala, S. L., Coulibaly, D., Thera, M. A., Dicko, A., Smith, D. L., Guindo, A. B., Kone, A. K., Traore, K., Ouattara, A., Djimde, A. A., Sehdev, P. S., Lyke, K. E., Diallo, D. A., Doumbo, O. K., \& Plowe, C. V. (2007). Dynamics of polymorphism in a malaria vaccine antigen at a vaccine-testing site in Mali. PLoS Medicine, 4(3), e93.

733 Thera, M. A., Doumbo, O. K., Coulibaly, D., Laurens, M. B., Ouattara, A., Kone, A. K., Guindo, A. B., Traore, K., Traore, I., Kouriba, B., Diallo, D. A., Diarra, I., Daou, M., Dolo, A., Tolo, Y., Sissoko, M. S., Niangaly, A., Sissoko, M., Takala-Harrison, S., ... Plowe, C. V.

738 Toenhake, C. G., Fraschka, S. A.-K., Vijayabaskar, M. S., Westhead, D. R., van Heeringen, S. 739 J., \& Bártfai, R. (2018). Chromatin Accessibility-Based Characterization of the Gene 740 Regulatory Network Underlying Plasmodium falciparum Blood-Stage Development. Cell Host \& Microbe, 23(4), 557-569.e9. https://doi.org/10.1016/j.chom.2018.03.007 
742 Tran, T. M., Ongoiba, A., Coursen, J., Crosnier, C., Diouf, A., Huang, C.-Y., Li, S., Doumbo, S.,

743

744

745

746

747

748

749

750

751

752

753

754

755

756

757

758

759

760

761

762

763

764

765

766

Doumtabe, D., Kone, Y., Bathily, A., Dia, S., Niangaly, M., Dara, C., Sangala, J., Miller, L. H., Doumbo, O. K., Kayentao, K., Long, C. A., ... Crompton, P. D. (2014). Naturally Acquired Antibodies Specific for Plasmodium falciparum Reticulocyte-Binding Protein Homologue 5 Inhibit Parasite Growth and Predict Protection From Malaria. The Journal of Infectious Diseases, 209(5), 789-798. https://doi.org/10.1093/infdis/jit553

Van der Auwera, G. A., Carneiro, M. O., Hartl, C., Poplin, R., Del Angel, G., Levy-Moonshine, A., Jordan, T., Shakir, K., Roazen, D., Thibault, J., Banks, E., Garimella, K. V., Altshuler, D., Gabriel, S., \& DePristo, M. A. (2013). From FastQ data to high confidence variant calls: The Genome Analysis Toolkit best practices pipeline. Current Protocols in Bioinformatics, 43, 11.10.1-33. https://doi.org/10.1002/0471250953.bi1110s43

van Schaijk, B. C. L., Ploemen, I. H. J., Annoura, T., Vos, M. W., Foquet, L., van Gemert, G.-J., Chevalley-Maurel, S., van de Vegte-Bolmer, M., Sajid, M., Franetich, J.-F., Lorthiois, A., Leroux-Roels, G., Meuleman, P., Hermsen, C. C., Mazier, D., Hoffman, S. L., Janse, C. J., Khan, S. M., \& Sauerwein, R. W. (2014). A genetically attenuated malaria vaccine candidate based on P. falciparum b9/slarp gene-deficient sporozoites. ELife, 3. https://doi.org/10.7554/eLife.03582

Vanegas, M., Bermúdez, A., Guerrero, Y. A., Cortes-Vecino, J. A., Curtidor, H., Patarroyo, M. E., \& Lozano, J. M. (2014). Protecting capacity against malaria of chemically defined tetramer forms based on the Plasmodium falciparum apical sushi protein as potential vaccine components. Biochemical and Biophysical Research Communications, 451(1), 15-23. https://doi.org/10.1016/j.bbrc.2014.06.143

Weedall, G. D., \& Conway, D. J. (2010). Detecting signatures of balancing selection to identify targets of anti-parasite immunity. Trends in Parasitology, 26(7), 363-369.

https://doi.org/10.1016/j.pt.2010.04.002 
WHO / World malaria report 2018. (n.d.). WHO. Retrieved May 30, 2019, from http://www.who.int/malaria/publications/world-malaria-report-2018/report/en/

Zainabadi, K., Adams, M., Han, Z. Y., Lwin, H. W., Han, K. T., Ouattara, A., Thura, S., Plowe, C. V., \& Nyunt, M. M. (2017). A novel method for extracting nucleic acids from dried blood spots for ultrasensitive detection of low-density Plasmodium falciparum and Plasmodium

773 Zhang, M., Wang, C., Otto, T. D., Oberstaller, J., Liao, X., Adapa, S. R., Udenze, K., Bronner, I.

774 F., Casandra, D., Mayho, M., Brown, J., Li, S., Swanson, J., Rayner, J. C., Jiang, R. H.

775 Y., \& Adams, J. H. (2018). Uncovering the essential genes of the human malaria

776 parasite Plasmodium falciparum by saturation mutagenesis. Science, 360(6388).

777 https://doi.org/10.1126/science.aap7847

778 Zhu, S. J., Almagro-Garcia, J., \& McVean, G. (2017). Deconvolution of multiple infections in

779 Plasmodium falciparum from high throughput sequencing data. Bioinformatics (Oxford, 780 England). https://doi.org/10.1093/bioinformatics/btx530 